\title{
The Turkish Adaptation of 15-Item Version of the Need for Cognitive Closure Scale and Relationship between Thinking and Decision-making Styles
}

\author{
Hasan Yilmaz \\ Department of Educational Sciences, Faculty of Letters, Kyrgyz-Turkish Manas University, Kyrgyzstan
}

Copyright $\bigcirc 2018$ by authors, all rights reserved. Authors agree that this article remains permanently open access under the terms of the Creative Commons Attribution License 4.0 International License

\begin{abstract}
Need for cognitive closure refers to the need to reach a precise knowledge instead of confusion and ambiguity on a subject and the desire to make a decision as soon as possible. The purpose of the present research is to adapt the "15-item version of the Need for Closure Scale" developed by Roets and Van Hiel to Turkish and testing the relationships between thinking and decision-making styles and the need for cognitive closure through the adapted scale. The work group consists of 577 people who voluntarily participated. Confirmatory factor analysis was used to test the validity of the scale. Cronbach's alpha reliability coefficient was calculated to test the reliability of scale scores. The research also utilized Thinking Styles Inventory developed by Sternberg and Wagner and Decision Making Styles scale developed by Scott and Bruce. According to the findings of the research, need for Cognitive Closure Scale is a valid and reliable instrument that can be used to study the attitudes towards cognitive closure in Turkey. Additionally, cognitive closure and thinking and decision-making styles are related; the need for cognitive closure can also be regarded as an approach to thinking and decision-making.
\end{abstract}

Keywords Need for Cognitive Closure, Thinking Styles, Decision-making Styles

\section{Introduction}

The need for cognitive closure, a concept coined by Kruglanski in the literature, refers to the need to reach a precise knowledge instead of confusion and ambiguity on a subject and the desire to make a decision as soon as possible. In other words; it is defined as the need to tendency to any answer, when the individual who encounters a case of decision-making and selection feels confused and uncertain. The motivation to simplify complex knowledge and to avoid uncertainty underlies the need for cognitive closure, which is also conceptualized as the need for cognitive completion [1]. Individuals' searching for information style being either quality based search or alternative based search defines their need for cognitive closure [2]. The need for closure is assumed to result from two general tendencies, urgency and permanence, respectively [3]. The urgency tendency is related to the desire to reach the closure as soon as possible. The permanence tendency refers to inclination to maintain closure as long as possible, thus "freezing" the current closure and assuring the future closure. According to Kruglanski [1], some individuals prefer to avoid uncertainty in a given situation, complete the mental uncertainty (cognitive completeness / closure) and certain, fixed and predictable situations. These choices increase the individual's need for cognitive completion. From this perspective, the need for cognitive closure is a structure, which influences people's perception of the social world. Additionally, the need for closure reflects a preference of certainty and stability, openness and certain rules, precise answers to questions, to uncertainty and lack of control. Individuals who need the closure dimension of personality are prone to adopting stereotypical judgments and are less inclined to accept the diversity. This structure is also related to the tendency to adhere to the rules, to reduce old beliefs and to accept the routine [4]. Individuals with a high need for completion also want immediate access to rapid decision-making that reflects their need for stability. Individuals with a high need for completion also want immediate access to rapid decision-making that reflects their need for stability. They also find situations they lack completion aversive and feel uncomfortable in case of uncertainty. Finally, they are conservative, since they are reluctant to be influenced by alternative thinking or inconsistent evidence [5]. Uncertainty refers to the inability to foresee the near or distant future, or the outcome of an event, situation or behavior [6]. The need for completion, in the simplest sense, is the orientation towards a cognitive completion to avoid negative emotions experienced when encountered with an uncertain situation. In this context, individuals with high levels of intolerance 
to uncertainty are expected to have a high need for completion. In other words, there is a positive relationship between intolerance to uncertainty and the need for cognitive completion. The most fundamental reason for this relationship being positive is that both characteristics bring along negative feelings such as anxiety. Individuals with high cognitive closure needs are also poor in coping with stress and problems. In his research, Ekşi [7] found that those with extrovert personality are more self-confident and use social support seeking coping styles more and reported that there was a significant relationship between openness to experiences, compatibleness and responsible personality traits and coping styles. According to Kashima et al. [8], humble individuals are more open to making meanings into new experiences and are more flexible under stress. On the other hand, individuals with a high need for cognitive closure close themselves to new experiences.

\section{Objectives}

There are two dimensions to the present research. The first of these is Turkish adaptation of the "15-item version of the Need for Closure Scale" developed by Roets and Van Hiel [5]. The second dimension is testing the relationship between thinking and decision-making styles and the need for cognitive closure through the adapted scale. In this framework, answers to the following questions are sought:

1. Is the Turkish adaptation of the Need for Cognitive Closure Scale developed by Roets \& Van Hiel [5] a valid and reliable tool to measure attitudes towards cognitive closure in Turkey?

2. Is there a relationship between cognitive closure and thinking styles, and which of the thinking style does cognitive closure predict to what extent?

3. Is there a relationship between cognitive closure and decision-making styles, and which of the decision-making style does cognitive closure predict to what extent?

\section{Related Literature}

The interest in the concept of need for cognitive closure produced many studies on the subject matter. Apart from the studies on the relationship between the concept of closure and demographic variables, the examples related to the previous studies in the literature are summarized below.

A study conducted to analyze the relationship between personality traits, cognitive closure and authoritarian tendencies [13]; reported a distinct and positive relationship between conscience, which is a sub-dimension of personality traits, and the need for cognitive closure. There is a significant and negative relationship between openness and experience and the need for cognitive closure.
The same study reported a moderate relationship between need for cognitive closure and authoritarianism, which was interpreted that individuals with higher needs for cognitive closure were more authoritarian.

Another study conducted to determine the effects of personal variables and positive / negative life experiences on need for cognitive closure [14] found that the need for cognitive closure was predicted significantly by age from personal variables. Additionally, a negative effect of closed mindedness dimension of cognitive closure was reported on resilience.

Studies have also been conducted on the relationship between attachment styles and the need for cognitive closure. In one of these studies; it has been observed that individuals with a secure attachment style prefer cognitive closure less. Researchers explained this finding with the relying on and searching for new information feature of individuals with low cognitive closure needs [15].

There are also studies reporting that high closure needs can produce positive results. Lee [16] reported that managers with high closure needs used an autocratic procedure for decision-making and problem solving; on the other hand managers with a high level of experience were found to reflect this positively on the performance of the company.

A study conducted on the relationship between crime related anxiety and risk sensitivity and cognitive closure needs on the samples of Italy, Bulgaria and Lithuania [17] found that individuals with high cognitive closure had high levels of crime related anxiety and risk sensitivity. Researchers related this finding with the tendency to avoid ambiguity, to prefer traditional, tried and usual methods in solving conflicts and to control result as soon as possible of the individuals with high need for closure.

Individuals with a high need for closure simplify their social relationships to reduce differences and uncertainty in their environment, require more conventional rules, and approach their environment with a prejudice that includes these strict rules [18]. In this regard, cognitive closure is closely related to psychopathology. A study on the effects of cognitive closure on symptoms of mental health and psychopathology [19] reported that cognitive closure explained $29 \%$ of psychopathological symptoms.

A study conducted on the samples of Europe, America and East Asia to test the invariance of need for cognitive closure found that the concept of cognitive closure need had the same basic meaning and construct in different cultures and the Need for Cognitive Closure Scale could be used to make comparisons between countries. The same study reported that the closure needs were significantly higher in the American and Korean samples compared to the Flemish and especially Poland samples [20]. A study conducted to test whether Webster and Kruglanski's [21] Need for Closure Scale was a reliable and valid tool to contribute to further motivation and social cognition studies, studied the effects of the ambiguity of the 
encountered task and the acquisition at the end of the task on cognitive closure [22]. The study found that while task ambiguity had no effect on the need for closure, the acquisition at the end of the task was a performance-enhancing factor on subjects with moderate and high cognitive closure needs. Researchers interpreted this finding as an effect of internal and external motivation on cognitive closure.

\section{Methods}

The work group consists of 577 people who voluntarily participated in the present research. $30.3 \%$ of the participants were male and $69.7 \%$ were female. Confirmatory factor analysis was used to examine the construct validity of the adapted version of the Need for Cognitive Closure Scale. Cronbach's alpha reliability coefficient was calculated to study the reliability of scale scores. After completing the adaptation dimension of the present research, the adapted version of the Need for Cognitive Closure Scale was implemented on a sample of 455 senior year university students along with thinking styles and decision-making style scales and the obtained results were analyzed. Information on the characteristics of the study group is shown in Table 1.

Table 1. Descriptive Characteristics of the Working Group

\begin{tabular}{|c|c|c|c|c|c|}
\hline & $\mathrm{f}$ & $\%$ & & $\mathrm{f}$ & $\%$ \\
\hline Gender & \multicolumn{5}{|c|}{ Faculty } \\
\hline Woman & 368 & 63.8 & Medical-Phar. & 43 & 7.5 \\
\hline Male & 209 & 36.2 & Engineering & 49 & 8.5 \\
\hline University & & & Science & 55 & 9.5 \\
\hline Selçuk & 189 & 32.7 & Communication & 65 & 11.3 \\
\hline NEU & 198 & 34.3 & Theology & 70 & 12.1 \\
\hline Manas & 190 & 33.0 & Education & 74 & 12.8 \\
\hline Age & & & Economics-Business & 81 & 14.0 \\
\hline $18-20$ & 274 & 47.5 & Literature & 65 & 11.3 \\
\hline $21-23$ & 213 & 36.9 & Fine Arts & 46 & 8.0 \\
\hline $24-26$ & 90 & $\begin{array}{l}50.9 \\
15.6\end{array}$ & Agriculture & 29 & 5.0 \\
\hline
\end{tabular}

\subsection{Data Collection Tools and Analysis Method}

Roets \& Van Hiel [5] developed the 15-item version of the Need for Cognitive Closure Scale, the original form of which consisted of 42 items and 5 dimensions, in 5 dimensions, each including 3 items considering the factor loads of the components. Roets \& Van Hiel [5] reported that the psychometric properties of the 15 -item version of the Need for Cognitive Closure Scale were the same as the 42-item form.

The second tool used in the present research is Thinking Styles Inventory, developed by Sternberg and Wagner [9] on the basis of "Mental Self-Government Theory" and adapted to Turkish by Buluş [10]. In the adaptation study, the original number of 104 items was reduced to 65 and a new short form of TSI of 65 items, including 5 items in each sub-dimension, was created. The calculated reliability (internal consistency) coefficients ranged between .64 and .89 for all subdimensions of the scale. Cronbach's Alpha internal consistency coefficient was calculated as .91 for the whole scale.

Another tool used in the present research is Decision Making Styles Scale, developed by Scott and Bruce [11] to measure individual differences in decision-making styles. Scott and Bruce [11] reported that the internal consistency coefficient for each subdimension ranged between .79 and .94. The scale was adapted to Turkish by Taşdelen [12]. In the adaptation study, alpha calculated for each subscale ranged between .76 and 78 are. Internal consistency was calculated as .74 for the whole scale.

Confirmatory factor analysis was used in data analysis to examine the construct validity of the Need for Cognitive Closure Scale. In order to test the reliability of the scale scores, the Cronbach alpha reliability coefficient was calculated. Correlations between variables were tested, and variance and regression analyses were used for the analysis of the relationships between cognitive closure and sub-dimensions of thinking and decision-making styles.

\subsection{Translation Work}

Need for cognitive closure scale was translated into Turkish according to the steps suggested by Brsilin and others [32]. These steps are as follows:

i. Translation into target language

ii. Evaluation of translation

iii. Back translation to the source language

iv. Evaluation of back translation

v. Expert opinion

Need for cognitive closure scale went through the same steps. The scale was translated into Turkish language by two separate professional translators. Translated forms were evaluated by the team consisting of two specialists in the aspects of clarity, simplicity, comprehensibility, concept equivalents and cultural conformity. After necessary changes the Turkish form of the scale was translated into source language by two specialists who were not involved in initial translation process. Some changes were made that will not affect the translation and final evaluation was done. As a last step of the translation stage the forms were given to two academicians to determine the appropriateness of translations and structures of scale items, after which final evaluation was done, where feedbacks were taken into account. Turkish and English forms of the scale were applied twice to 30 senior students of Translation department Kyrgyz-Turkish Manas University with one month break; and high correlation between two applications was found (.984).

\section{Results}

Some of the hypotheses were tested before conducting the analyses. The fitness of the data to factor analysis was 
tested with Kaiser-Mayer-Olkin (KMO) coefficient and Barlett test. For the fitness of the data, KMO coefficient should be higher than 0.60 and Bartlett test results should be significant [33]. According to the fitness tests conducted before factor analyses, Kaiser-Mayer-Olkin (KMO) coefficient was 0,86 and Bartlett value was 1076.409 $(\mathrm{p}<.000)$, which indicated that data were fit for Explanatory Factor Analysis (EFA).

\subsection{Findings Related to Turkish Adaptation of 15 -item Version of the Need for Closure Scale}

Confirmatory factor analysis was used to verify five-factor structure of the scale, which was obtained [5]. The goodness of fit indices obtained as a result of the analysis was showed in Table 2. Figure 1 presents the measurement model formed by standardized solutions.

Table 2. Results of goodness-of-fit test for perceived value and perceived risk CFA

\begin{tabular}{cccccccc}
\hline Model & $\chi^{2}$ & $\chi^{2} / d f$ & $p$ & CFI & GFI & NFI & RMSEA \\
\hline Perceived value & 113.22 & 1.42 & 0.00 & 0.99 & 0.93 & 0.96 & 0.039 \\
\hline $\begin{array}{c}\text { Recommended } \\
\text { value }\end{array}$ & $\leq 3$ & & $\geq 0.90$ & $\geq 0.90$ & $\geq 0.90$ & $\leq 0.080$ \\
\hline
\end{tabular}

When Table 2 was examined, it is seen that indexes of goodness of fit are among the values suggested in the literature. The statistic $\chi^{2}$ was $113.12(d f=80)$ with the $\chi^{2} / d f$ ratio having a value of 1.42 ; less than 5 which indicates an acceptable fit. The goodness fit indexes were $\mathrm{CFI}=0.99$; $\mathrm{GFI}=0.93$; $\mathrm{NFI}=0.96$; RMSEA $=0.039$. Values above 0.90 are considered good, and above 0.95 is an excellent model fit. RMSEA should be below the recommended level of 0.08 . These values indicated that the five factor structure of the scale had a reasonably satisfactory goodness of fit and the previously identified five factor structure of the scale was supported in a sample of Turkish university students. However, when figure 1 was examined, it was seen that factor loadings of the items varied between 0.19 and 0.83 . It was expected that the factor loading values in the literature were higher than 0.30 ; but item 14 had 0.19 of factor loading value. Therefore item 14 was excluded from the analysis, the data were analyzed again.

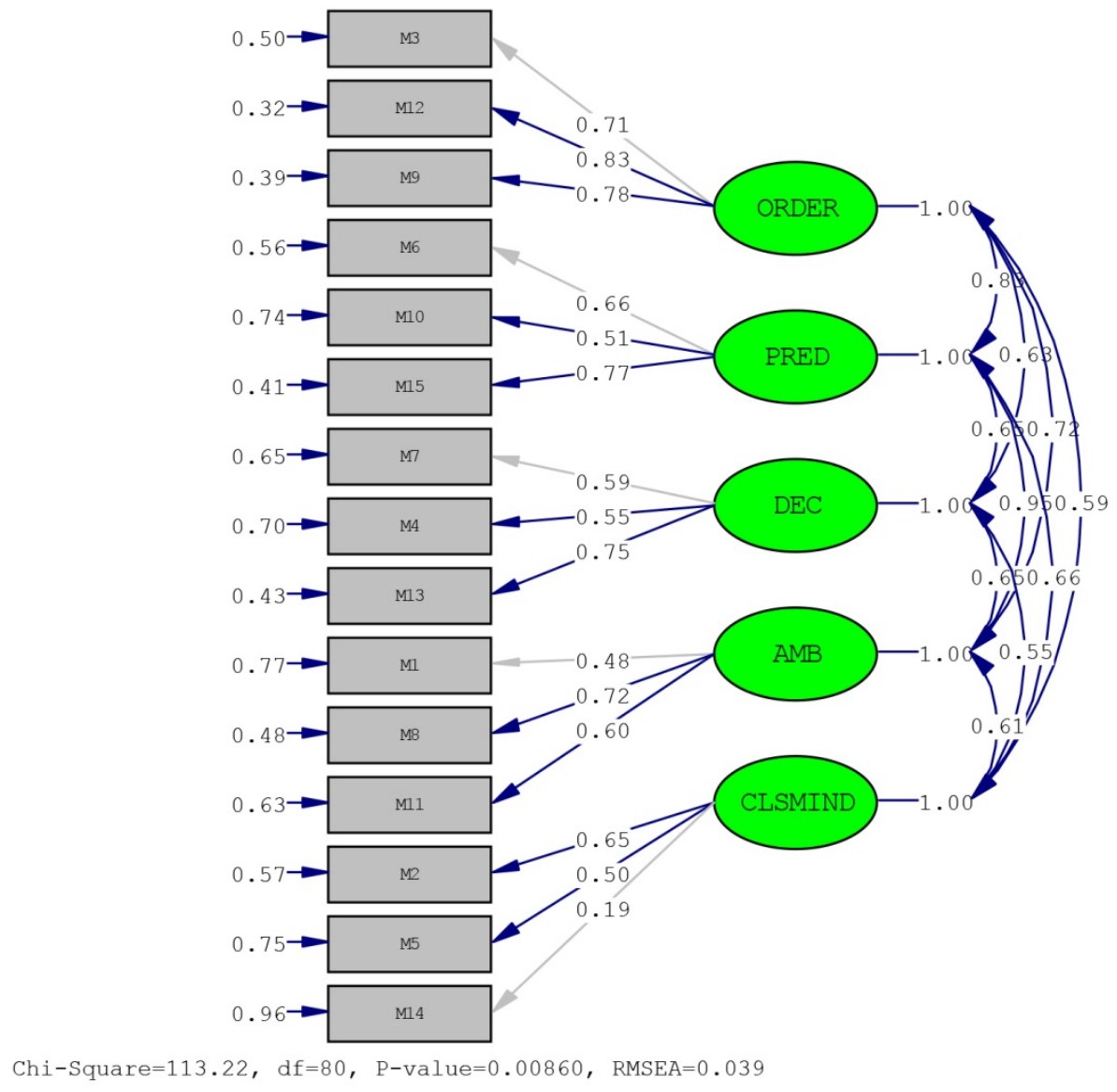

Figure 1. Standardized solution of the first order CFA of Need for Closure Scale (PRED: Predictability, DEC: Decisiveness, AMB: Ambiguity, CLSMIND: Closed-mindedness)

After item 1 was excluded from the analysis, the goodness of fit indexes obtained as a result of confirmatory factor analysis was showed in Table 3 . Figure 2 presents the measurement model formed by standardized solutions. 
Table 3. Results of goodness-of-fit test for perceived value and perceived risk CFA

\begin{tabular}{cccccccc}
\hline Model & $\chi^{2}$ & $\chi^{2} / d f$ & $p$ & CFI & GFI & NFI & RMSEA \\
\hline Perceived value & 95.55 & 1.43 & 0.00 & 0.99 & 0.94 & 0.97 & 0.039 \\
\hline Recommended value & & $\leq 3$ & & $\geq 0.90$ & $\geq 0.90$ & $\geq 0.90$ & $\leq 0.080$ \\
\hline
\end{tabular}

When Table 3 was examined, it is seen that indexes of goodness of fit are among the values suggested in the literature. The statistic $\chi^{2}$ was $95.55(d f=867)$ with the $\chi^{2} / d f$ ratio having a value of 1.42 ; less than 5 which indicates an acceptable fit. The goodness fit indexes were $\mathrm{CFI}=0.99$; $\mathrm{GFI}=0.94 ; \mathrm{NFI}=0.97$; RMSEA $=0.039$. Values above 0.90 are considered good, and above 0.95 is an excellent model fit. RMSEA should be below the recommended level of 0.08 . These values indicated that the five factor structure of the scale had a reasonably satisfactory goodness of fit and the previously identified five factor structure of the scale was supported in a sample of Turkish university students. It was also seen that factor loadings of the items varied between 0.49 and 0.83 . Factor loading for Need for Closure facet scale expected that the factor loading values in the literature.

Table 4. The Distribution of İtems for Factors and Percentages of Variance They Explained

\begin{tabular}{cccccc}
\hline & Order & Predictability & Decisiveness & Ambiguity & Closed-Mindedness \\
\hline M3 & .711 & & & \\
M12 & .833 & & & & \\
M9 & .782 & & & & \\
\hline M6 & & .662 & & & \\
M10 & .510 & & & \\
M15 & .770 & & & \\
\hline M7 & & .601 & & \\
M4 & & .554 & & \\
M13 & & .752 & & \\
\hline M1 & & & .783 & .621 \\
M8 & & & & \\
M11 & & & & \\
\hline M2 & & & & \\
M5 & & & & \\
\hline
\end{tabular}

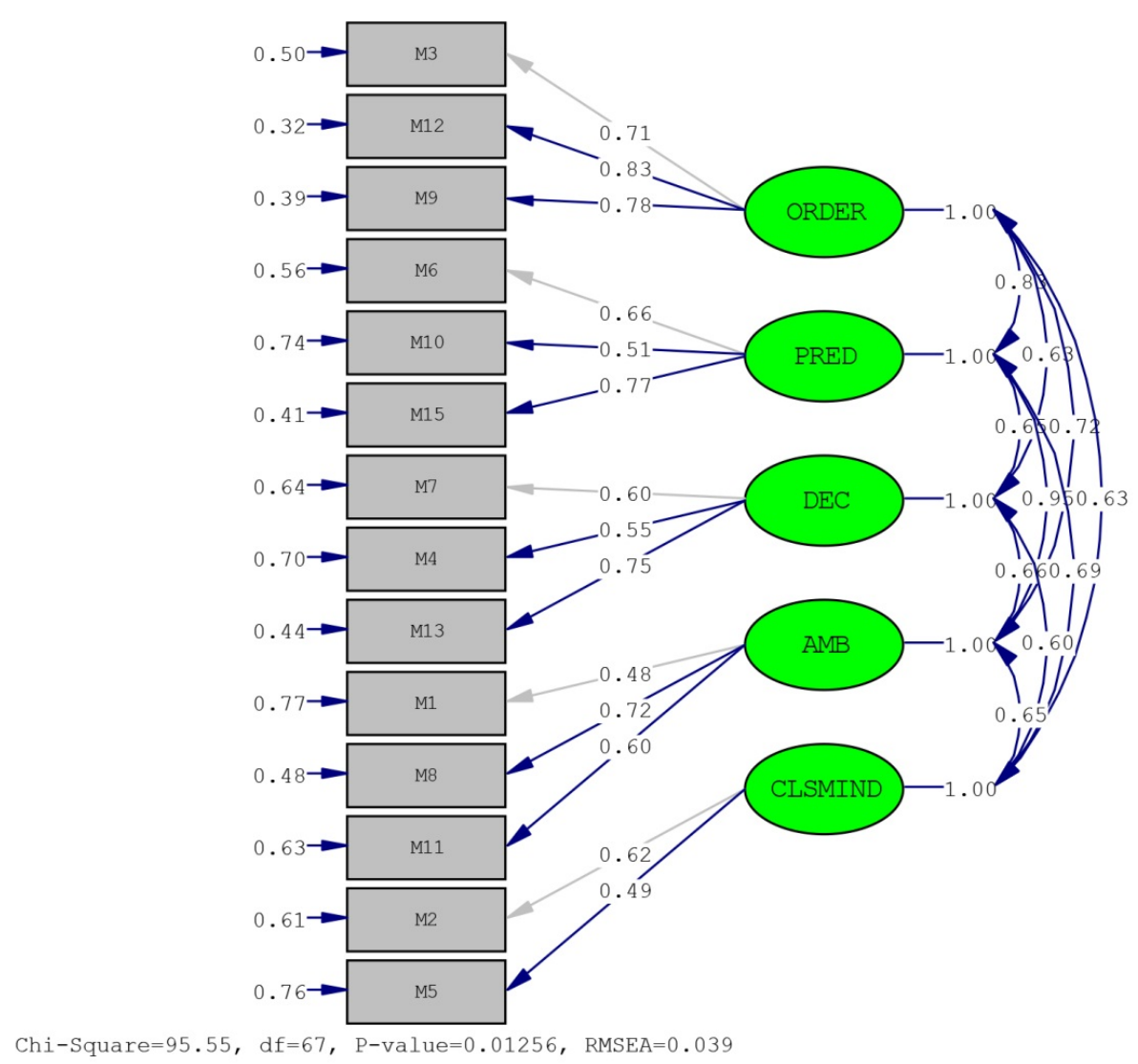

Figure 2. Standardized solution of the first order CFA of Need for Closure Scale (PRED: Predictability, DEC: Decisiveness, AMB: Ambiguity, CLSMIND: Closed-mindedness) 
Reliability: The scale was administered to a sample of 277 adults for reliability studies. Internal consistency reliability of the scale, measured by Cronbach alpha, was 0.85 for 15 -item version of the Need for Closure Scale and was 0.86 for 14 -items.

\subsection{The Relationship between Cognitive Closure and Thinking Styles}

Conducted analyses revealed significant relationships between cognitive closure and executive, judicial, monarchical, hierarchical and conservative thinking styles. Related findings are presented in Table 5.

There is a moderate $(\mathrm{r}=.435)$ correlation between executive thinking style and cognitive closure. Additionally, cognitive closure can explain about $19 \%$ of executive thinking style $\left(\mathrm{r}^{2}=.189\right)$. Taken all 5 sub-dimensions of cognitive closure (order search, predictability, decisiveness, ambiguity and closed mindedness) together, there is a significant relationship between cognitive closure and executive thinking style $(\mathrm{F}=4.388 ; \mathrm{p}<.001)$. According to the beta values; the sub-dimensions of cognitive closure that most effects the executive thinking style are ambiguity $(\beta=.433)$ and order $(\beta=.388)$. The sub-dimension that least affects the executive thinking style is predictability $(\beta=.093)$.

There is also a moderate $(\mathrm{r}=.389)$ correlation between judicial thinking style and cognitive closure. Cognitive closure can explain about $15 \%$ of judicial thinking style $\left(\mathrm{r}^{2}=.152\right)$. Taken all 5 sub-dimensions of cognitive closure (order, predictability, decisiveness, ambiguity and closed mindedness) together, there is a significant relationship between cognitive closure and judicial thinking style $(\mathrm{F}=3.396 ; \mathrm{p}<.004)$. The sub-dimensions of cognitive closure that most affect the judicial thinking style are predictability $(\beta=.470)$, closed mindedness $(\beta=.395)$ and ambiguity $(\beta=.274)$. The sub-dimensions that least affect the judicial thinking style are decisiveness $(\beta=.079)$ and order $(\beta=.033)$. In agreement with beta values, there are significant relationships between judicial thinking style and predictability $(\mathrm{t}=-2.444 \quad \mathrm{p}<.016)$ and closed mindedness $(\mathrm{t}=-2.402 ; \mathrm{p}<.018) \quad$ sub-dimensions score averages.

Table 5. Relationship between Cognitive Closure and Thinking Styles

\begin{tabular}{|c|c|c|c|c|c|c|c|c|}
\hline & & ORDER & PRED & $\mathrm{DEC}$ & AMB & $\begin{array}{c}\text { CLS } \\
\text { MIND }\end{array}$ & $\begin{array}{c}\text { Cognitive Closure } \\
\text { (General) }\end{array}$ & Model \\
\hline \multirow{5}{*}{ Executive } & B & ,451 &,- 108 & ,253 & ,622 & 230 &,- 128 & \multirow{5}{*}{$\begin{array}{c}\mathrm{R}=.435 \\
\mathrm{R}^{2}=.189 \\
\mathrm{~F}=4.388 \\
\mathrm{Sig}=\mathbf{. 0 0 1} *\end{array}$} \\
\hline & S.Er & ,200 & ,217 & ,205 & ,302 & ,239 &, 176 & \\
\hline & Beta & ,388 &,- 093 & ,194 & ,433 & ,154 &,- 351 & \\
\hline & $\mathrm{t}$ & 2,252 &,- 497 & 1,231 & 2,058 & ,958 &,- 725 & \\
\hline & Sig. & ,026 & ,620 &, 221 &, $042 *$ &, 340 & ,470 & \\
\hline \multirow{5}{*}{ Judicial } & B &,- 042 &,- 600 &,- 114 & ,437 &,- 652 & ,219 & \multirow{5}{*}{$\begin{array}{c}\mathrm{R}=.389 \\
\mathrm{R}^{2}=.152 \\
\mathrm{~F}=3.396 \\
\mathrm{Sig}=\mathbf{. 0 0 4} *\end{array}$} \\
\hline & S.Er & 227 & ,246 & ,233 & ,341 & ,271 & ,199 & \\
\hline & Beta &,- 033 &,- 470 &,- 079 &, 274 &,- 395 &, 546 & \\
\hline & $\mathrm{t}$ &,- 187 & $-2,444$ &,- 490 & 1,282 & $-2,402$ & 1,097 & \\
\hline & Sig. & ,852 &, 016 &, 625 & ,203 &, $018 *$ & ,275 & \\
\hline \multirow{5}{*}{ Monarchical } & B & ,116 & ,012 & ,130 &,- 371 & ,238 & ,095 & \multirow{5}{*}{$\begin{array}{c}\mathrm{R}=.436 \\
\mathrm{R}^{2}=.190 \\
\mathrm{~F}=4.376 \\
\mathrm{Sig}=\mathbf{. 0 0 1} *\end{array}$} \\
\hline & S.Er & ,181 & ,196 & ,186 & ,272 & ,218 & ,159 & \\
\hline & Beta & ,112 & ,011 & , 110 &,- 285 & ,177 & ,287 & \\
\hline & $\mathrm{t}$ & ,642 & ,059 & ,701 & $-1,363$ & 1,090 &, 594 & \\
\hline & Sig. &, 522 & ,953 & ,485 & ,176 & ,278 &, 554 & \\
\hline \multirow{5}{*}{ Hierarchical } & B & ,198 &,- 237 & ,238 &,- 442 &,- 279 &, 184 & \multirow{5}{*}{$\begin{array}{c}\mathrm{R}=.362 \\
\mathrm{R}^{2}=.131 \\
\mathrm{~F}=2.867 \\
\mathrm{Sig}=\mathbf{. 0 1 2} *\end{array}$} \\
\hline & S.Er & ,242 & ,261 & 247 & ,363 & ,289 &, 212 & \\
\hline & Beta & ,148 &,- 177 & , 157 &,- 263 &,- 161 & ,437 & \\
\hline & $\mathrm{t}$ & ,818 &,- 909 & ,963 & $-1,219$ &,- 967 & ,868 & \\
\hline & Sig. & ,415 & ,365 & ,338 & ,225 & ,336 & ,387 & \\
\hline \multirow{5}{*}{ Conservative } & B & ,412 & ,210 & ,048 &,- 731 & ,634 &, 022 & \multirow{5}{*}{$\begin{array}{c}\mathrm{R}=.497 \\
\mathrm{R}^{2}=.247 \\
\mathrm{~F}=6.221 \\
\mathrm{Sig}=. \mathbf{0 0 0} *\end{array}$} \\
\hline & S.Er & ,260 & ,282 & ,267 & ,391 & ,311 &, 228 & \\
\hline & Beta & ,266 & ,135 &, 027 &,- 376 & ,316 &, 045 & \\
\hline & $\mathrm{t}$ & 2,582 & ,746 &, 180 & 2,094 & 2,038 & ,095 & \\
\hline & Sig. &, $019 *$ & ,457 &, 858 &, $041 *$ &, $044 *$ & ,924 & \\
\hline
\end{tabular}

(PRED: Predictability, DEC: Decisiveness, AMB: Ambiguity, CLSMIND: Closed-mindedness) 
There is a moderate $(r=.435)$ correlation between executive thinking style and cognitive closure. Additionally, cognitive closure can explain about $19 \%$ of executive thinking style $\left(\mathrm{r}^{2}=.189\right)$. Taken all 5 sub-dimensions of cognitive closure (order search, predictability, decisiveness, ambiguity and closed mindedness) together, there is a significant relationship between cognitive closure and executive thinking style $(\mathrm{F}$ $=4.388 ; \mathrm{p}<.001)$. According to the beta values; the sub-dimensions of cognitive closure that most effects the executive thinking style are ambiguity $(\beta=.433)$ and order $(\beta=.388)$. The sub-dimension that least affects the executive thinking style is predictability $(\beta=.093)$.

There is also a moderate $(r=.389)$ correlation between judicial thinking style and cognitive closure. Cognitive closure can explain about $15 \%$ of judicial thinking style $\left(r^{2}=.152\right)$. Taken all 5 sub-dimensions of cognitive closure (order, predictability, decisiveness, ambiguity and closed mindedness) together, there is a significant relationship between cognitive closure and judicial thinking style $(\mathrm{F}=$ 3.396; $p<.004)$. The sub-dimensions of cognitive closure that most affect the judicial thinking style are predictability $(\beta=.470)$, closed mindedness $(\beta=.395)$ and ambiguity $(\beta=.274)$. The sub-dimensions that least affect the judicial thinking style are decisiveness $(\beta=.079)$ and order $(\beta=.033)$. In agreement with beta values, there are significant relationships between judicial thinking style and predictability $(\mathrm{t}=-2.444 \quad \mathrm{p}<.016)$ and closed mindedness $(\mathrm{t}=-2.402 ; \mathrm{p}<.018) \quad$ sub-dimensions score averages.

There is a moderate relationship $(r=.436)$ between the monarchical thinking style and cognitive closure. Cognitive closure can explain about $19 \%$ of monarchical thinking style $\left(\mathrm{r}^{2}=.189\right)$. Taken all 5 sub-dimensions of cognitive closure (order, predictability, decisiveness, ambiguity and closed mindedness) together, there is a significant relationship between cognitive closure and monarchical thinking style $(\mathrm{F}=4.376 ; \mathrm{p}<.001)$. According to the results of the analyses, the sub-dimensions of cognitive closure that most affect the monarchical thinking style are ambiguity $(\beta=.285)$ and closed mindedness $(\beta=.177)$. The sub-dimension that least affects the monarchical thinking style is predictability $(\beta=.011)$.

According to the findings of the present research, conservative thinking style is the thinking style that has the highest correlation with cognitive closure $(\mathrm{r}=.497)$. Cognitive closure can explain about $25 \%$ of conservative thinking style $\left(\mathrm{r}^{2}=.247\right)$. Taken all 5 sub-dimensions of cognitive closure (order, predictability, decisiveness, ambiguity and closed mindedness) together, there is a significant relationship between cognitive closure and conservative thinking style $(\mathrm{F}=6.221 ; \mathrm{p}<.000)$. The sub-dimensions of cognitive closure that most affect the conservative thinking style are ambiguity $(\beta=.376)$, closed mindedness $(\beta=.316)$ and order $(\beta=.266)$. The sub-dimension that least affects the conservative thinking style is decisiveness $(\beta=.027)$. According to $t$ values obtained in the analyses, there are significant relationships between conservative thinking style and three sub-dimensions of cognitive closure. These are; order ( $\mathrm{t}=$ $2.582, \mathrm{p}<.019)$, ambiguity $(\mathrm{t}=-2.094 \mathrm{p}<.041)$ and closed mindedness $(\mathrm{t}=-2.038 ; \mathrm{p}<.044)$.

\subsection{The Relationship between Cognitive Closure and Decision-Making Styles}

Conducted analyses revealed significant relationships between cognitive closure and intuitive, avoidant and spontaneous decision-making styles. Related findings are presented in Table 6.

Table 6. The Relationship between Cognitive Closure and Decision-Making Styles

\begin{tabular}{|c|c|c|c|c|c|c|c|c|}
\hline & & ORDER & PRED & DEC & AMB & CLS MIND & $\begin{array}{c}\text { Cognitive } \\
\text { Closure } \\
\text { (General) }\end{array}$ & Model \\
\hline \multirow{5}{*}{ Intuitive } & B &,- 008 &,- 268 & ,595 &,- 306 &,- 217 & , 166 & \multirow{5}{*}{$\begin{array}{c}\mathrm{R}=.404 \\
\mathrm{R}^{2}=.163 \\
\mathrm{~F}=3.712 \\
\mathrm{Sig}=.002 * *\end{array}$} \\
\hline & S.Er & ,264 & ,285 &, 270 & ,396 &, 315 & ,231 & \\
\hline & Beta &,- 005 &,- 179 &, 352 &,- 164 &,- 112 & ,354 & \\
\hline & $\mathrm{t}$ &,- 029 &,- 940 & 2,202 &,- 773 &,- 688 & ,716 & \\
\hline & Sig. & ,977 & ,349 &, 030 & ,441 & ,493 & ,476 & \\
\hline \multirow{5}{*}{ Avoidant } & B &,- 277 &,- 130 &,- 123 &,- 571 & ,611 & ,266 & \multirow{5}{*}{$\begin{aligned} \mathrm{R} & =.380 \\
\mathrm{R}^{2}= & .144 \\
\mathrm{~F} & =3.202 \\
\mathrm{Sig} & =.006^{* *}\end{aligned}$} \\
\hline & S.Er & ,338 & 366 &, 346 &, 508 &, 404 & 297 & \\
\hline & Beta &,- 147 &,- 069 &,- 057 &,- 241 &, 250 & ,448 & \\
\hline & $\mathrm{t}$ &,- 820 &,- 357 &,- 354 & $-2,124$ & 2,512 & 898 & \\
\hline & Sig. & ,414 & ,722 &, 724 &, $026 * *$ & $.010^{* *}$ &, 371 & \\
\hline \multirow{5}{*}{ Spontaneous } & B &,- 401 &,- 444 &, 412 &,- 500 &,- 043 & ,281 & \multirow{5}{*}{$\begin{aligned} \mathrm{R} & =.381 \\
\mathrm{R}^{2}= & .145 \\
\mathrm{~F} & =3.197 \\
\mathrm{Sig} & =.006^{* * *}\end{aligned}$} \\
\hline & S.Er & ,280 &, 303 &, 287 & ,421 &, 335 & 246 & \\
\hline & Beta &,- 258 &,- 284 & ,233 &,- 255 &,- 021 &, 573 & \\
\hline & $\mathrm{t}$ & $-2,048$ & $-1,966$ & 2,436 & $-1,988$ &,- 128 & 1,143 & \\
\hline & Sig. &, $040^{*}$ &, $045^{*}$ & ,024* &, $037^{*}$ & 899 & ,256 & \\
\hline
\end{tabular}


There is a moderate relationship $(\mathrm{r}=.404)$ between the intuitive decision-making style and cognitive closure. Cognitive closure can explain about $16 \%$ of intuitive decision-making style $\left(\mathrm{r}^{2}=.163\right)$. Taken all 5 sub-dimensions of cognitive closure (order, predictability, decisiveness, ambiguity and closed mindedness) together, there is a significant relationship between cognitive closure and intuitive decision-making style $(\mathrm{F}=3.712 ; \mathrm{p}<.002)$. The sub-dimensions of cognitive closure that most affect the intuitive decision-making style are decisiveness $(\beta=.352)$, predictability $(\beta=.179)$ and ambiguity $(\beta=.164)$. The sub-dimension that least affects the intuitive decision-making style is order $(\beta=.005)$. There is a significant relationship between intuitive decision-making style and decisiveness sub-dimension of cognitive closure $(\mathrm{t}=2.202 ; \mathrm{p}<.030)$.

There is a moderate relationship $(\mathrm{r}=.380)$ between the avoidant decision-making style and cognitive closure. Cognitive closure can explain about $14.4 \%$ of avoidant decision-making style $\left(\mathrm{r}^{2}=.144\right)$. Taken all 5 sub-dimensions of cognitive closure (order, predictability, decisiveness, ambiguity and closed mindedness) together, there is a significant relationship between cognitive closure and avoidant decision-making style $(\mathrm{F}=3.202 ; \mathrm{p}<.006)$. The sub-dimensions of cognitive closure that most affect the avoidant decision-making style are closed mindedness $(\beta=.250)$, ambiguity $(\beta=.241)$ and order $(\beta=.147)$. The sub-dimensions that least affect the avoidant decision-making style are predictability $(\beta=.069)$ and decisiveness $(\beta=.057)$. There are significant relationships between avoidant decision-making style and ambiguity $(\mathrm{t}=$ $-2.124, \mathrm{p}<.026)$ and closed mindedness $(\mathrm{t}=2.512, \mathrm{p}<.010)$ sub-dimensions of cognitive closure.

There is a moderate relationship $(r=.381)$ between the spontaneous decision-making style and cognitive closure. Cognitive closure can explain about $14.5 \%$ of spontaneous decision-making style $\left(\mathrm{r}^{2}=.145\right)$. Taken all 5 sub-dimensions of cognitive closure (order, predictability, decisiveness, ambiguity and closed mindedness) together, there is a significant relationship between cognitive closure and spontaneous decision-making style $(\mathrm{F}=3.197 ; \mathrm{p}<.006)$ The sub-dimensions of cognitive closure that most affect the spontaneous decision-making style are predictability $(\beta=.284)$, order $(\beta=.258)$, ambiguity $(\beta=.255)$ and decisiveness $(\beta=.233)$. The sub-dimension that least affects the spontaneous decision-making style is closed mindedness $(\beta=.021)$. There are significant relationships between spontaneous decision-making style and order $(\mathrm{t}=$ $-2.048, \mathrm{p}<.030)$, predictability $(\mathrm{t}=-1.966, \mathrm{p}<.045)$, decisiveness $(\mathrm{t}=2.436, \mathrm{p}<.021)$ and ambiguity $(\mathrm{t}=-1.988$, $\mathrm{p}<.037$ ) sub-dimensions of cognitive closure.

\section{Discussion}

One of the purposes of the present research is adapting the 15-item version of the Need for Cognitive Closure
Scale to Turkish and studying the psychometric properties of the scale for Turkish samples. In accordance with this purpose, confirmatory factor analysis was conducted and internal consistency was tested. Confirmatory factor analysis was conducted to prove the five-factor structure developed by Roets and Van Hiel [5]. According to the results of confirmatory factor analysis, although fit indices used to test the data fit of five-dimensional structure for 15 items presented good fit, the factor load value for one of the items was lower than 0.30. For this reason, one of the items was excluded and the analyses were re-conducted. Based on the results of confirmatory factor analysis conducted again with 14 items, the items presented very good fit with the data and the factor loads for all items were higher than 0.30. Cronbach's alpha coefficient was calculated to test the internal consistency of the scale, and it was found as 0.86 . Accordingly, the internal consistency of the scale is high. In short, according to the analyses conducted on the 14-item version, the Need for Cognitive Closure Scale is a valid and reliable instrument that can be used to study attitudes towards cognitive closure in Turkey. This finding is in agreement with the findings of the studies conducted on the applicability of the scale on different cultures [5].

Another dimension of the present research is based on the hypothesis that the need for cognitive closure is closely related to thinking and decision making styles.

One of the most widely accepted theories on thinking styles is the Mental Self-Government Theory coined by Sternberg. In this theory, Sternberg presented a tendency to unite cognitive and personality approaches. The main point of the theory is based on the idea that people need to manage themselves and regulate their daily activities like societies do [23]. Cognitive Closure is a structure that affects the way people perceive the social world. Closure refers to the preferences of certainty and stability, openness and certain rules, precise answers to questions, and avoidance of ambiguity [4]. These definitions produce the expectation that there is a significant relationship between thinking styles and cognitive closure. This expectation has been confirmed to a great extent with the findings of the present research, which show significant relationships between cognitive closure and five of the thinking styles indicated in the Mental Self-Management Theory.

Individuals who have executive thinking style like following and adhering to rules and love structured problems. Individuals with this style of thinking are compatible and organized people, who like to follow the instructions given. Rather than creating a structure of their own, they love to use existing structures [24,25].

The finding of the present research that there is a significant relationship between cognitive closure and executive thinking style is in complete agreement with this definition. Especially the relationships between the order and ambiguity sub-dimensions of cognitive closure and executive thinking style reinforce this finding.

Individuals with judicial thinking style like evaluating rules and procedures and comparing and analyzing events 
and facts. These individual take the consequences of the actions of other individuals into consideration and focus on evaluating them. Individuals with judicial thinking style succeed in explaining their thoughts, writing criticisms and evaluating the programs [26]. The negative correlations between close mindedness and predictability sub-dimensions of cognitive closure and judicial thinking style is an important finding of the present research, because close-mindedness and predictability completely contradict with comparing and analyzing facts, taking actions of other individuals into account characteristics of judicial thinking style. This finding is in complete agreement with our theory that there is a relationship between cognitive closure and thinking styles.

Individuals with a monarchical thinking style concentrate on a single goal. They do not allow obstacles to prevent them from solving problems. They either are indifferent to the obstacles or ignore them. They prefer to do one thing at once by consuming all their energy resources [27]. Taken the definition of the monarchical thinking style into account, the present research has revealed an important finding about the relationship between cognitive closure and thinking styles. Considering that there may be many variables affecting the thinking styles that cognitive closure predicts $19 \%$ of the monarchical thinking style is a significant finding.

Individuals with hierarchical thinking style can pay attention on a lot of different works and work by setting priority orders. Individuals with this style tend to enjoy paying effort on more than one goal, to know that some goals are more important than others, to have the ability to set priorities and to be systematic in their approach to problem-solving. They tend to be systematic and organized when solving problems or making decisions [28].

The findings of the present research that the " $\mathrm{B}$ " value, "beta" and "t" values calculated between hierarchical thinking style and predictability, ambiguity and close-mindedness sub-dimensions of cognitive closure are negative are in complete agreement with the content of hierarchical thinking style. Another important finding of the present research is that cognitive closure can explain $13 \%$ of hierarchical thinking style.

According to the findings of the present research, cognitive closure has the highest correlation with conservative thinking style. Individuals with conservative thinking style like to act in accordance with existing rules and procedures, avoid resistance, and stay away from ambiguous situations whenever possible. They prefer the familiar in their lives [29]. That cognitive closure can explain $25 \%$ of conservative thinking style is an important finding of the present research. That the results of $t$ test conducted to test the relationship between order, close mindedness and ambiguity sub-dimensions of cognitive closure and conservative thinking style are significant is in agreement with this conclusion.

Significant relationship between intuitive, avoidant, and spontaneous decision making styles and cognitive closure is another important finding of our research.

In the most general sense, decision-making is the process of selecting one of the various ways an individual believes to lead to their goals. That is, decision-making can be defined as an act to solve a problem when there is more than one way leading to the object, which is believed to meet a need [11]. Findings of the present research that are related to the relationship between decision-making styles and cognitive closure are important as they reveal overlapping of the contents of the decision making with cognitive closure.

Intuitive decision-making style is characterized by attention to details in the flow of information, reliance on emotions and intuitions in decision-making, rather than systematic research and information processing. Intuitive decision makers focus more on imagination, feelings and emotions [11]. According to the findings of the research, cognitive closure can predict $16 \%$ of intuitive decision-making. Additionally, the significance of the result of $t$ test for the relationship between decisiveness sub-dimension of cognitive closure and intuitive decision-making is also a proof of the relationship between these two variables.

Individuals with avoidant decision-making style avoid making the decision in every possible situation, and postpone decision-making as late as possible. Individuals with an avoidant decision-making style tend to avoid responsibility for the decision they must make [30]. In the present research, the beta values calculated for the relationships between the avoidant decision-making style and the four sub-dimensions of cognitive closure (order, predictability, decisiveness and ambiguity) were negative. Additionally, $\mathrm{t}$ value for the relationship between ambiguity sub-dimension and avoidant decision-making is also negative, and this value is statistically significant. This finding is important as it reveals that the characteristic feature of cognitive closure; making a decision as soon as possible to get rid of stress is contrary to the postponing decision feature of avoidant decision-making. Even the $t$ test result for the relationship between the closed-mindedness sub-dimension of cognitive closure and avoidant decision-making is not significant; it is in agreement with our interpretation. 
Even its relationship between spontaneous decision-making is significant considering the definition of cognitive closure, it is important as it presents the relationship between decision-making styles and cognitive closure. People with spontaneous decision-making style complete decision-making task as quickly as possible, in haste, without thinking and without considering alternative solutions [31]. This definition is in agreement with all characteristics of cognitive closure. The finding that the $t$ test results for the relationships between order, predictability, decisiveness and ambiguity sub-dimensions of cognitive closure and spontaneous decision-making style are significant also supports this interpretation.

The present research found that cognitive closure could explain $15 \%$ of spontaneous decision-making.

\section{Conclusions and Limitations}

Cognitive closure and thinking and decision-making styles are interrelated processes. Cognitive closure can adequately predict and explain both thinking and decision-making styles. Research has shown that the need for cognitive closure can also be regarded as an approach to thinking and decision-making.

\section{The Limitations of the Study}

The Need for Closure Scale is a scale less well known in Turkey. In this case, there are very few studies using this scale. In the future, 14-Item Version of The Need for Closure Scale studies with different dimensions of cognitive closure to the understanding and clearer will help the discussion. The psychometric properties of the adapted scale were carried out on university students. It is suggested to apply the scale on different samples and to make analyzes.

\section{Appendix}

Turkish Adaptation of 14-item version of the Need for Closure Scale

\begin{tabular}{|c|c|c|c|c|c|c|c|}
\hline & & Kesinlikle KATILMIYORUM & Orta Derecede KATILMIYORM & Az KATILMIYORUM & Biraz Katıliyorum & $\begin{array}{l}\text { Orta Derecede } \\
\text { Katıliyorum }\end{array}$ & Kesinlikle Katıllyorum \\
\hline 1 & $\begin{array}{c}\text { Belirsiz olan durumlardan } \\
\text { hoşlanmiyorum. }\end{array}$ & & & & & & \\
\hline 2 & $\begin{array}{c}\text { Birçok farklı şekilde } \\
\text { cevaplanabilecek soruları } \\
\text { sevmiyorum. }\end{array}$ & & & & & & \\
\hline 3 & $\begin{array}{c}\text { Yapılacak her işin } \\
\text { zamanının belli olduğu, iyi } \\
\text { planlanmış bir hayat } \\
\text { mizacıma uygun } \\
\text { buluyorum. }\end{array}$ & & & & & & \\
\hline 4 & $\begin{array}{c}\text { Bir sorunla karşı karşıya } \\
\text { kaldığımda, çok çabuk bir } \\
\text { çözüme ulaşmak için acele } \\
\text { ederim. }\end{array}$ & & & & & & \\
\hline 5 & $\begin{array}{c}\text { Bir grupta, herkesin aynı } \\
\text { fikirde olduğu bir şeye bir } \\
\text { kişi karşı çıktığında rahatsız } \\
\text { oluyorum } \\
\end{array}$ & & & & & & \\
\hline
\end{tabular}


The Turkish Adaptation of 15-Item Version of the Need for Cognitive Closure Scale and Relationship between Thinking and Decision-Making Styles

\begin{tabular}{|c|c|c|c|c|c|}
\hline 6 & $\begin{array}{c}\text { Ne ile karşılaşacağımı } \\
\text { bilmediğim bir durumun } \\
\text { içine girmek istemem }\end{array}$ & & & & \\
\hline 7 & $\begin{array}{c}\text { Karar vermem gereken bir } \\
\text { durumda, bir an önce karar } \\
\text { verdiğimde rahatladığımı } \\
\text { hissederim. } \\
\end{array}$ & & & & \\
\hline 8 & $\begin{array}{c}\text { Nedenini anlayamadığım } \\
\text { bir olay meydana } \\
\text { geldiğinde rahatsız } \\
\text { oluyorum } \\
\end{array}$ & & & & \\
\hline 9 & $\begin{array}{l}\text { Kuralları açıkça belli olan } \\
\text { düzenli bir yaşam tarzına } \\
\text { sahip olmaktan hoşlanırım }\end{array}$ & & & & \\
\hline 10 & $\begin{array}{l}\text { Beklenmedik eylemlerde } \\
\text { bulunabilecek insanlarla } \\
\text { birlikte olmak istemem. }\end{array}$ & & & & \\
\hline 11 & $\begin{array}{c}\text { Bir kişinin sözü çok farklı } \\
\text { anlamlara geliyorsa rahatsız } \\
\text { olurum. }\end{array}$ & & & & \\
\hline 12 & $\begin{array}{l}\text { Düzenli ve istikrarlı bir } \\
\text { hayat tarzı sahip olmak } \\
\text { hayatı daha keyifli kılar }\end{array}$ & & & & \\
\hline 13 & $\begin{array}{l}\text { Bir soruna derhal çözüm } \\
\text { bulamazsam, sabırsızlanır } \\
\text { ve rahatsız olurum }\end{array}$ & & & & \\
\hline 14 & $\begin{array}{c}\text { Öngörülemeyen, tahmin } \\
\text { edilemeyen durumlardan } \\
\text { hoşlanmam }\end{array}$ & & & & \\
\hline \multicolumn{2}{|c|}{$\begin{array}{c}\text { Order } \\
\text { (Düzen Arama) }\end{array}$} & $\begin{array}{c}\text { Predictability (Öngörülebilirlik } \\
\text { Tahmin edilebilirlik ihtiyacı) }\end{array}$ & $\begin{array}{c}\text { Decisiveness } \\
\text { (Hızlı Karar Verme) }\end{array}$ & $\begin{array}{c}\text { Ambiguity } \\
\text { (Belirsizlikten rahatsiz olma) }\end{array}$ & $\begin{array}{l}\text { closed-mindedness } \\
\text { (Sabit Fikirlilik) }\end{array}$ \\
\hline \multicolumn{2}{|r|}{$3-12-9$} & $6-10-14$ & $7-4-13$ & $1-8-11$ & $2-5$ \\
\hline
\end{tabular}




\section{REFERENCES}

[1] A. W. Kruglanski, D. M. Webster. Motivated Closing of the Mind: 'Seizing' and 'Freezing', Psychological Review 1996, Vol. 103, No. 2, 263-283, 1996.

[2] A. V. Hiel, I. Mervielde. The Need for Closure and the Spontaneous Use of Complex and Simple Cognitive Structures, The Journal of Social Psychology, Vol. 143, No. 5, 559-568, 2003.

[3] D. M. Webster, A. W. Kruglanski. Cognitive and Social Consequences of the Need for Cognitive Closure, European Review of Social Psychology, Vol. 8, No. 1, 133-173, 1997.

[4] I. Todor. Need for Closure and Cognitive Inhibition of Unwanted or Irrelevant Information, Procedia - Social and Behavioral Sciences, Vol. 141, 712-717, 2014.

[5] A. V. Hiel, A. Roets. Item Selection And Validation of A Brief, 15-Item Version of The Need for Closure Scale, Personality and Individual Differences, Vol. 50, 90-94, 2011.

[6] S. Sarı. Sürekli kaygının yordayıcıları olarak belirsizliğe tahammülsüzlük, endişe ile ilgili inançlar ve kontrol odağının incelenmesi. Master Thesis, Ankara, Hacettepe University, 2007.

[7] H. Ekşi. Üniversite Öğrencilerinin Kişilik Özellikleri ile Başa Çıkma Tarzları: Kanonik Korelasyonel Bir Analiz, Kuram ve Uygulamada Eğitim Bilimleri, Vol. 10 No. 4, 2141-2176, 2010.

[8] E. S. Kashima, T. Greiner, G. Sadewo, S. Ampuni, L. Helou, V. Nguyen, B. C. P. Pan Lam, K. Kaspar. Open- and closed-mindedness in cross-cultural adaptation: the roles of mindfulness and need for cognitive closure, International Journal of Intercultural Relations, Vol. 59, 31-42, 2017.

[9] R. J. Sternberg, R. K. Wagner. Thinking Styles Inventory. Unpublished Test, Yale University, New Havan, CT, 1992.

[10] M. Buluş. Assessment of Thinking Styles Inventory, Academic Achievement and Student Teacher's Characteristics, Education and Science, Vol. 31, No. 139, 35-48, 2006.

[11] S. G. Scott, R. A. Bruce. Decision Making Style, The Development And Of A New Measure, Educational and Psychological Measurement, Vol. 55, No.5, 818-831, 1995.

[12] Taşdelen, A. Decision-Making Styles of Teacher Candidates According to Different Psycho-social Variables. Unpublished PhD Thesis. Izmir: Dokuz Eylül University Educational Sciences Institute.

[13] H. Ekşi, S. Parlak, E. Sevim. Investigation of the Relationship Between Personality Traits, Cognitive Closure and Authoritarian Tendencies, AGP Humanities and Social Sciences Conference, p. 279-287, Berlin, 2016.

[14] E. Arı, G. Cesur, S. Cömertoğlu, E. Turak. Bilişsel Kapalılık İhtiyacı, Yaşam Olayları ve Psikolojik Sağlamlık Arasındaki İlişkilerin İncelenmesi, 53. Ulusal Psikiyatri Kongresi, Mersin, 2017. http://www.upk2017.org

[15] M. Mikulincer. Adult Attachment Style and Information Processing: Individual Differences in Curiosity and Cognitive Closure, Journal of Personality and Social Psychology, Vol. 72, No. 5, 1217-1230, 1997.

[16] Y. Lee. Decision-Making Uncertainty, Need for Cognitive Closure, and Supply Chain Performance, Doctoral Dissertation, Cleveland State University, 2011 http://rave.ohiolink.edu/etdc/view?acc_num $=$ csu 13016872 09

[17] J. Jackson. Cognitive closure and risk sensitivity in the fear of crime, Legal and Criminological Psychology, Vol. 20, No. 2, 222-240, 2013.

[18] H. Atak, M. Syed, F. Çok, Z. Tonga. Need for Closure as a New Neuropsychological Concept, Psikiyatride Güncel Yaklaşımlar-Current Approaches in Psychiatry, Vol. 8, No. 3, 290-302, 2016.

[19] A. Roets, B. Soetens. Need and Ability to Achieve Closure: Relationships with symptoms of psychopathology, Personality and Individual Differences, Vol. 48, No. 2, 155-160, 2010.

[20] M. Kossowska, A. Van Hiel, W. Y. Chun, A. W. Kruglanski. The Need for Cognitive Closure scale: structure, cross-cultural invariance, and comparison of mean ratings between European-American and East Asian samples, Psychologica Belgica, Vol. 42, No. 4, 267-286, 2002.

[21] D. M. Webster, A. W. Kruglanski. Individual Differences in Need for Cognitive Closure, Journal of Personality and Social Psychology, Vol. 67, No. 6, 1049-1062, 1995.

[22] V. Viola, A. Tosoni, A. Brizi, I. Salvato, A. W. Kruglanski, G. Galati, L. Mannetti. Need for Cognitive Closure Modulates How Perceptual Decisions Are Affected by Task Difficulty and Outcome Relevance, PLoS ONE, Vol. 10, No. 12, 1-13, 2015.

[23] R. J. Sternberg, L. F. Zhang. Styles of Thinking as a Basis of Differentiated Instruction, Theory into Practice, Vol. 44, No. 3, 245-253, 2005.

[24] E. L. Grigorenko, R. J. Sternberg. Styles of Thinking, Abilities and Academic Performance, Exceptional Children, Vol. 63, No. 3, 295-312, 1997.

[25] L. F. Zhang. Thinking Styles and Modes of Thinking: Implications For Education And Research, The Journal of Psychology, Vol. 136, 245-261, 2002.

[26] L. F. Zhang. Thinking Styles across Cultures: Their Relationships with Student Learning in Perspective on Thinking, Learning and Cognitive Styles, R. J. Sternberg, L. F. Zhang (Eds), Lawrence Erlbaum Associates Publishers, London, 197-225, 2001.

[27] S. K. Park, K. H. Park, H. S. Choe. The relationship between thinking styles and scientific giftedness in Korea, The Journal of Secondary Gifted Education, Vol. 16, No. 2/3, 87-97, 2005.

[28] B. Wändi, A. P. Rand, B. Fischhoff. Individual Differences in Adult Decision-Making Competence, Journal of Personality and Social Psychology, Vol. 92, No. 5, 938-957, 2007. 
[29] A. Roets, A. V. Hiel. Need for closure relations with authoritarianism, conservative beliefs and racism: The impact of urgency and permanence tendencies, Psychologica Belgica, Vol. 46, No. 3, 235-252, 2006.

[30] S. D. Philips, N. J. Pazienza, H. H. Ferrin. Decision Making Styles and Problem Solving Appraisal, Journal of Counseling Psychology, Vol. 31, No. 4, 497-502, 1984.

[31] P. Thunholm. Decision Making Style: Habit, Style or Both?
Personality and Individual Differences, Vol. 36, No. 4 931-944, 2004.

[32] Brislin, R., W., Lonner, W., J., ve R.M. Thorndike, R., M. (1973). Cross Cultural Research Methods, New York: John Willey \& Sons Pub. S.182.

[33] Büyüköztürk, Ş. (2007). Sosyal bilimler için veri analizi el kitabı (7. Baskı). Ankara: Pegem Akademi Yayınları. 